\title{
FIRE AND EVACUATION IN HIGH RESIDENTIAL BUILDINGS
}

\author{
UDC 614.84:728.2
}

\author{
Radoje Jevtić \\ Electrotechnical School "Nikola Tesla", Niš, Serbia
}

\begin{abstract}
Although the term 'evacuation' implies the fastest, the safest and the shortest way of leaving the endangered objects, a place or a situation, it is not always the case with people, animals and property. It is very difficult to evacuate people from certain objects, due to their own properties, despite all safety measures. High-rise buildings and buildings with lot of occupants pose a particular challenge for evacuation. There are many reasons for that, but the most important is human behavior under stress and panic attack. Even beside all safety measures, education and training, it is almost impossible to predict someone`s behavior in stressful situations. This can have a huge influence on evacuation procedure since it can reduce the likelihood of evacuation, demand longer evacuation time and cause human toll. To support this idea, this paper has been written to show the importance of all factors needed to analyze and use all available resources to predict the development of evacuation and protect human lives and property.
\end{abstract}

Key words: evacuation, building, human, simulation.

\section{INTRODUCTION}

The "evacuation" is a very old term which dates back to the 18 th century when it implied to remove from a military area after the battle was lost. Later, the term was used to refer to the civilians, animals and property. There has been many similar definitions for evacuation, but each of them, no matter how different they were, generally implies that evacuation is "planned, organized and temporary but rapid relocation of people, animals, material and cultural property, state bodies and other legal forms from an endangered territory to a safe territory, determined by emergency plan". [1] If it takes several months or becomes permanent, then it can be called an emergency plan.[2]

Evacuation is a consequence of different reasons: wars, bomb threats, terrorist attack, earthquakes, fires, gas and chemical overflows, destructive winds, industrial and plant accidents, nuclear accidents, volcano eruptions, etc. Different evacuation situations demand the actions of various organization structures: military units, fire brigades, police forces,

Received June 25, 2018 / Accepted October 23, 2018

Corresponding author: Radoje Jevtić

Electrotechnical School "Nikola Tesla", Aleksandra Medvedeva 18, 18000 Niš, Serbia

E-mail: milan.jvtc@gmail.com 
civil protection forces, or very often-synchronized actions. Stuff must be properly chosen, organized, trained and educated, and very importantly, they must be familiar with modern technological and scientific solutions in order to precisely predict crisis and successfully complete evacuation [3].

Particularly hard and complex tasks are the evacuations from buildings and locations with occupants. This means the evacuation from residential buildings, trade and shop centers, theatres, hospitals, stadiums, airports, islands, and similar. It is impossible to predict human and animal behavior under stress, panic and danger, which can reduce the evacuation possibilities or completely neutralize them. The evacuation itself is the situation that causes stress and panic; people and animals are usually terrified and mostly governed by instinct, taking care only about their lives. Sometimes, some of the occupants cannot survive and their dead bodies significantly increase stress and panic among the living ones.

On 11 September 2001, 2996 people were killed (including 19 terrorists) and more than 6000 were wounded. Out of four kidnaped airplanes, two were crashed in World Trade Center in New York while the third airplane was crashed in the Pentagon and passengers or kidnapers in the rural part of Pennsylvania shot down the fourth airplane. The buildings were not designed for mass evacuation and every building (tower) had only three narrow stairwells that led to ground. Many people, who were mostly employed in buildings, jumped in the abyss below them, jumped into fire or on the others who tried to escape in great panic.

On 26 December 2004, a mega thrust earthquake occurred in several areas in Asia (Sri Lanka, Indonesia, Myanmar, Malaysia, India, Maldives, Thailand and others) and caused between 230.000-280.000 deaths and a lot of missing. Waves from the tsunami crashes were 15-30 m high, which caused panic and fear among people and animals. ,

More than 400 people died and more than 6600 were injured in a strong earthquake at the Iran and Iraq crossing, on November 13th, 2017. The number of missing persons is unknown. According to the Iranian National organization for accidents management, the Kermanshah province was the most effected and three days of mourning were declared. Many of them died or were injured because evacuation was impossible or delayed. There were the presumptions that over 70.000 people lost their homes. The earthquake was also felt in Iraq, where seven people died. The strength of the earthquake was between 6.5 and 7.5 Richter magnitude scale.

In a fire in a tall financial building in Mumbai (India) on December 29th, 2017, 15 persons died and more than 50 were injured. Fire started at the top of the building and only 30 minutes were enough for the building to be completely destroyed.

In terrible fire in a tall building in London over 70 people died and the building was destroyed (June 14th, 2017). The building had 27 floors with 120 flats and about 600 occupants. The exact number of people who were in the building at the moment when fire started remained unknown. Toxic gases, inappropriate building material and impossibility of evacuation contributed to the high number of victims.

Catastrophic floods killed 14 people and caused hundreds to be trapped by mud, slime and obstacles in Greece, at the west part of Athens (November 15th, 2017). Many institutions were closed while some parts of the Athens-Corinth highway were completely unreachable. Only in Mandra, 5 persons were drowned by water or mud. Nea Peramos and Megara were also among the worst affected places.

The facts mentioned above show how the catastrophes can be fast, unpredictable and destructive, and very often with lot of human victims. It also emphasized the importance 
of evacuation for people and property. There are a lot of factors that influence the time needed for the evacuation from a facility or an area: number of exits, number of floors, number of people (occupants), people (occupants) movement speed, dimensions of stairs, width of door and its opening direction, number of rescuers and their synchronization and team work, boats, vehicles, helicopters, etc.

\section{DANGER FROM FIRE IN HIGH-RISE BUILDINGS}

According to structural measurements of fire protection, objects can be classified in terms of their purpose as residential objects, business objects, public objects, industrial objects, stores and high-rise buildings. High buildings are, for example, residential buildings where the highest floor is at least $30 \mathrm{~m}$ above the lowest ground level and there is a free access for firefighter's vehicles. The appearance of tall buildings in architecture brought about new problems in fire protection-in terms of extinguishing and evacuation. For example, in the case of residential and business buildings, the main vertical communication space (elevators and stairs) is located in the middle of the object and directly linked to flats, business rooms and offices, which is a good and rational solution. However, in case of fire, they become useless for extinguishing and evacuation. Many high-rise buildings do not have fire stairs (buildings with two or more entrances with connected roofs). In case of fire, one of the most important recommendations is not to use the elevators, so it implies that the only possible evacuation route is stairs endangered by smoke and fire that spread to the top of the building. All tall buildings are divided into fire sectors and their dimensions depend from the height. Every fire sector should have at least one available safety stairs. Bearing wall, constructions and parts of evacuations routes must be made from non-combustible material. There are a lot of preventive measures that exceed the limitations of this paper and whose task is to prevent fire and, if fire occurs, to provide the evacuation of people endangered. , ,

Fire in a tall building is very hard to predict due to the fact that there can be different reasons for fire. However, extinguishing at higher floors implies the usage of mobile equipment, fire ladders and fire platform. The priority related to the extinguishment is the action of rescuing and evacuating endangered people. The evacuation in that case implies panic elimination, cooling and protection of communication routes if it is possible, the organization and following of evacuation process, and other potential tasks.

Fire brigades use different tactics and means to protect and save greater number of endangered people. Water fog is used as a fire protection means during the evacuation; fire brigades also have the installations with compressed air and oxygen that can also be used. Fire brigadiers attack from inside, trying to come closer to the fire and endangered people; at the same time, fire brigadiers from outside are trying to come closer to the endangered place with hydraulic telescopic platforms. These types of platforms can receive several people (often six to eight) and place them at the safe area. The last versions of hydraulic platform can reach heights up to 100 meters.

However, tall buildings appear everyday, many of them are even higher than 100 or 150 meters (e.g. Jeddah Tower $(1000 \mathrm{~m})$ - Jeddah in Saudi Arabia that is expected to be open till 2020; Wuhan Greenland Centre $(636 \mathrm{~m})$ - Wuhan in China that is expected to be finished till 2018; Merdeka PNB118 (630m) - in Kula Lumpur in Malaysia that is expected to be open till 2020; Ping An Finance Centre (599m) - in Shenzhen in China that was 
opened in 2016; Tianjin CTF Finance Centre (530m) - in Tianjin in China and many others). Some of the tallest buildings are presented in figure 1.

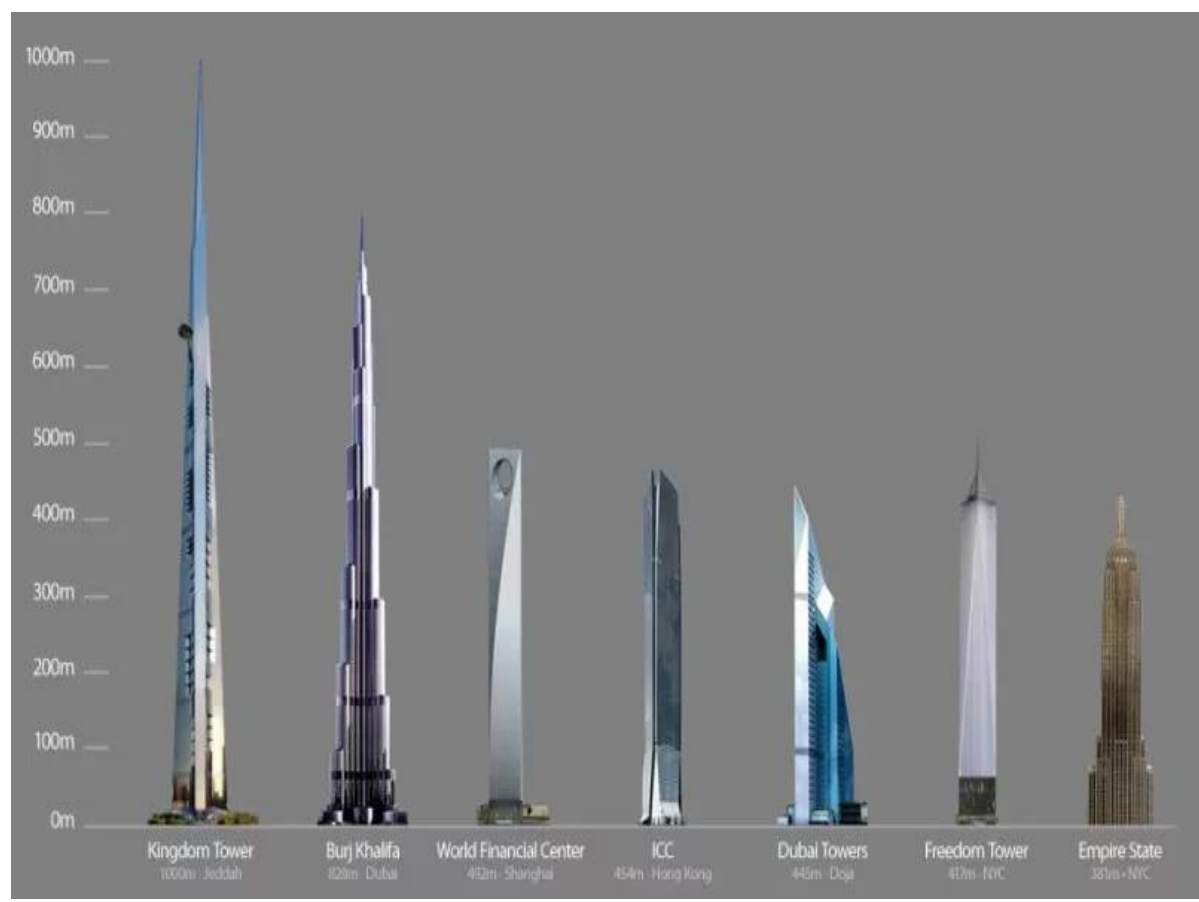

Fig. 1 Some of the tallest buildings in the world (figure source: https:/gizmodo.com/ 5826867/the-first-image-of-the-worlds-new-tallest-building)

In Serbia, the height of buildings is significantly below 100 or 150 meters (the highest buildings are Ušće building in Belgrade- about 141 meters, Genex Tower (known as western gate of Belgrade) which is 135 meters high, Beogradjanka building which is 101 meters high, and the buildings Rudo A, B and C about 100 meters high. Other buildings in Belgrade and all over Serbia are below 100 meters). Therefore, any kind of evacuation from the buildings mentioned above would be very difficult and with great chance of failure. Due to that, one of the most important safety measurements is to predict potential fire sources, fire and smoke spread and evacuation possibilities of the object - how long it takes people to leave the object and go to the safe place. In addition, it is important to know which evacuation routes can be used in the building, whether they can use lifts and similar things. One of the most useful, the most effective and the safest ways to predict the evacuation is the usage of appropriate simulation software. This software enables good prediction of fire spreading, smoke spreading and calculation of time needed for complete evacuation in an object, and therefore it has great appliance in fire protection. This software is good in case of objects occupied by lot of people, such as buildings, schools, hospitals, hotels and similar. 
The aim of this paper was to present the simulation of fire and evacuation by usage of FDS software and Pathfinder software in simulation of fire end evacuation in high building with fire stairs and lifts.

\section{A Simulation Model OF High-Rise BuILding}

Simulation models of high-rise buildings for this paper were done in FDS and Pathfinder simulation software (including different versions of these programmes). The calculating mechanisms of these programmes were explained in earlier papers and the appropriate manuals.

Dimensions of the high building were $20 \mathrm{~m}$ x $20 \mathrm{~m}$ x $41.6 \mathrm{~m}$. The high building was constructed as a residential building with 16 floors, two passenger elevators, stairs between flats and fire stairs.

Stairs between floors were made from concrete. The length of stairs was $4.687 \mathrm{~m}$, while the width of these stairs was $1.1 \mathrm{~m}$. The riser and tread dimensions were $17.9 \mathrm{~cm}$ and 28 $\mathrm{cm}$. Stairs space during the fire is a kind of a "chimney" with certain dimensions, which caused smoke to spread. For that reason, stairs must be isolated from all other rooms.

Fire stairs must provide continuous and undisturbed way to the safe area. They can be outer and inner. Outer fire stairs must not be in a spiral shape. Inner fire stairs must be surrounded by non-combustible material with fire resistance for at least two hours. Also, fire stairs space must be secured from smoke during fire. The smallest width of fire stairs was determined by rule that for every hundred occupants it shall not be lower than $0.6 \mathrm{~m}$, while the fire stairs width must not be lower than $1.25 \mathrm{~m}$, as it was stated in the paper .

There were two different scenarios: the first scenario implied the evacuation of occupants from building using stairs between flats while the second scenario implied the evacuation of occupants using evacuation stairs. In both scenarios, passenger elevators were not used for evacuation. The total number of occupants was 256 (each floor has four flats, each flat has four occupants). The high building in FDS presentation and Pathfinder presentation are presented in figure $1(\mathrm{a}$ and $\mathrm{b}$ ) and figure 2 ( $\mathrm{a}$ and $\mathrm{b})$. Because of many details, only basic shapes were presented in figures 2 and 3 while the rest was not and they were hidden by HIDE function.

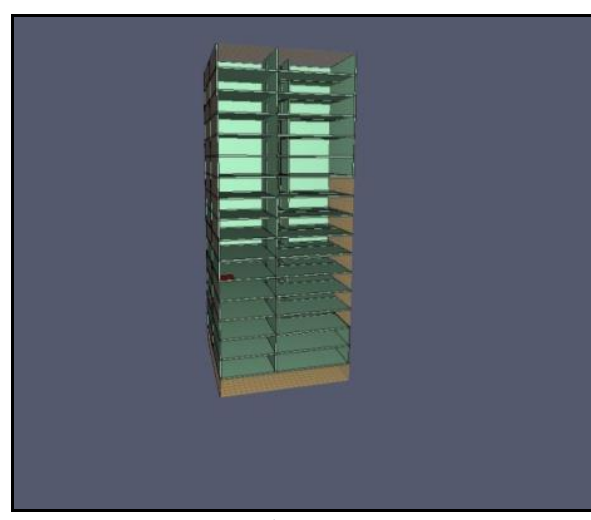

a)

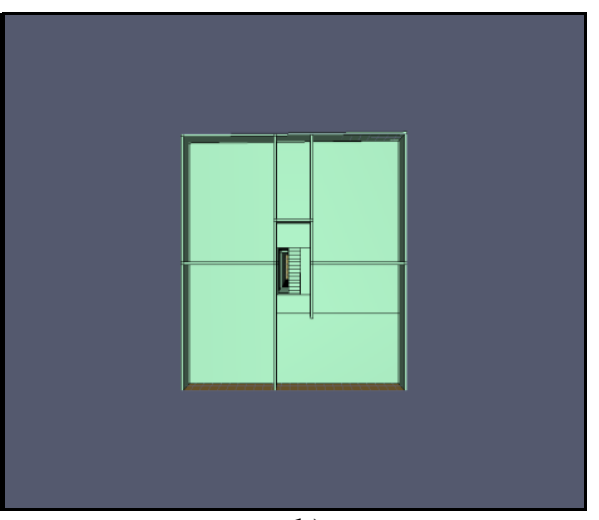

b)

Fig. 2 FDS presentation of high building, front view (a) and roof view (b) 


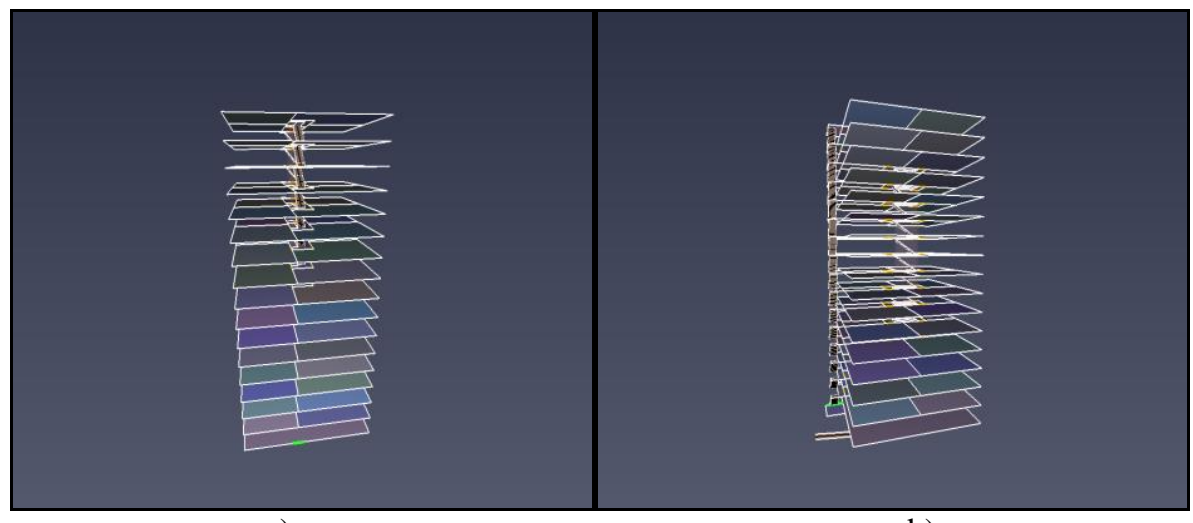

a)

b)

Fig. 3 Pathfinder presentation of high building, without (a) and with fire stairs (b)

\section{SimUlation AND SimULATION RESUltS}

In the first place, the simulation of fire was done to show the potential spreading of fire and smoke through the building volume. After that, simulations of occupant evacuation were carried out for two different scenarios and different speed of occupants. Simulation time was set to 300 seconds. The "place" where the fire started was the corner in a flat on the sixth floor. The fire source was modeled as a burner with dimensions of $0.9 \mathrm{~m} \times 0.7 \mathrm{~m}$ and HRR (Heat release rate per area) was $3500 \mathrm{kw} / \mathrm{m} 2$.

The first scenario implied the calculation of evacuation times for occupants who used only stairs between the floors and whose speeds were $0.7 \mathrm{~m} / \mathrm{s}, 0.9 \mathrm{~m} / \mathrm{s}, 1 \mathrm{~m} / \mathrm{s}, 1.2 \mathrm{~m} / \mathrm{s}$, $1.4 \mathrm{~m} / \mathrm{s}$ and $1.5 \mathrm{~m} / \mathrm{s}$, respectively. The second scenario implied the calculation of evacuation times for occupants that used fire stairs only, with the speeds of $0.7 \mathrm{~m} / \mathrm{s}, 0.9 \mathrm{~m} / \mathrm{s}, 1 \mathrm{~m} / \mathrm{s}$, $1.2 \mathrm{~m} / \mathrm{s}, 1.4 \mathrm{~m} / \mathrm{s}$ and $1.5 \mathrm{~m} / \mathrm{s}$, respectively. Simulation times were set to 800 seconds, while the times needed for simulations were longer. Passenger elevators were been used in both scenarios because of many references that elevators should not be used in evacuation (occupants can get stuck or trapped, potential presence of danger gasses such as CO-carbon monoxide, and other). Due to the limitations in paper size, only some of simulation scenes are presented.

Simulation of fire in high building in FDS software after 1.6 seconds, 60.2 seconds, 190.8 seconds and 280 seconds from the fire start is presented in figures 4 and 5 ( $\mathrm{a}$ and $\mathrm{b}$ ).

For the first scenario, the simulation of evacuation in high-rise building at the beginning and after 205.5 seconds is presented in figure 6 ( $\mathrm{a}$ and $\mathrm{b}$ ); for the second scenario the simulation of evacuation in high building after 139 seconds and after 439.6 seconds is presented in figure 7 ( $a$ and $b$ ).

The situations when occupants can get potentially stuck are presented in figure 8 ( $\mathrm{a}$ and $\mathrm{b}$ ).

The complete simulation results for occupant speed $(0.7 \mathrm{~m} / \mathrm{s}, 0.9 \mathrm{~m} / \mathrm{s}, 1 \mathrm{~m} / \mathrm{s}, 1.2 \mathrm{~m} / \mathrm{s}, 1.4$ $\mathrm{m} / \mathrm{s}$ and $1.5 \mathrm{~m} / \mathrm{s}$ ), for both scenarios, are presented in figures 9 and 10 . 


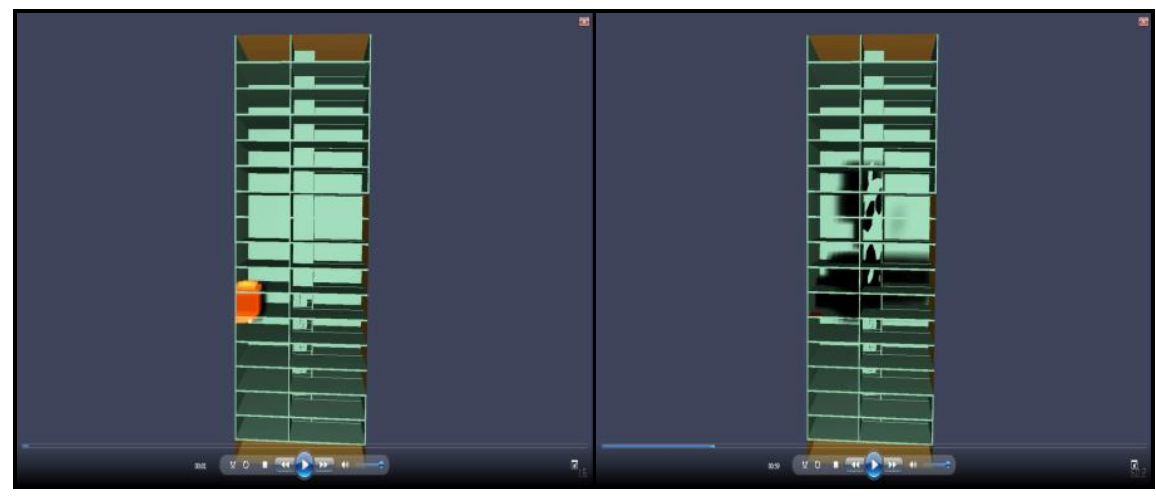

a)

b)

Fig. 4 Simulation of fire in a high-rise building after 1.6 seconds (a) and after 60.2 seconds (b) from the beginning of fire

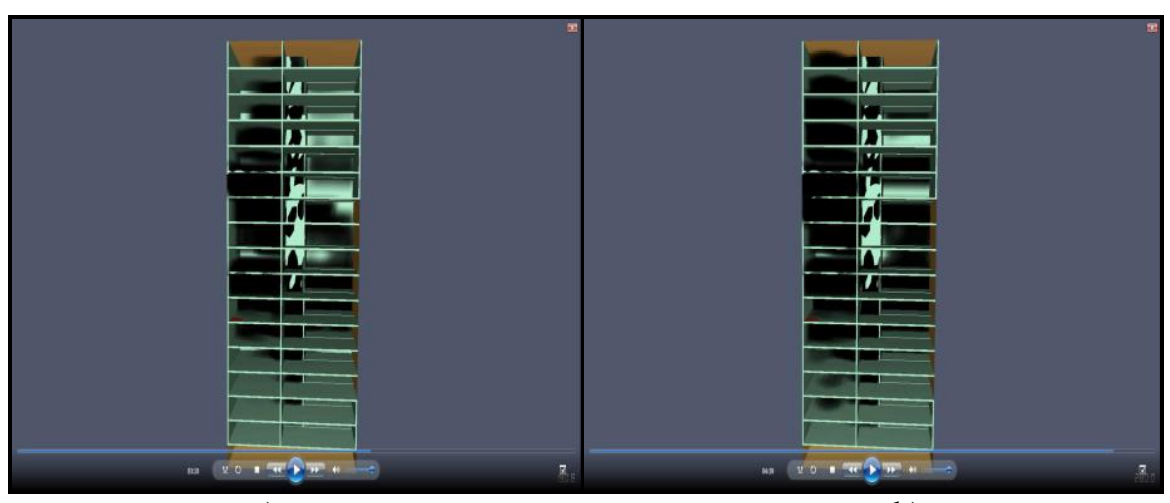

a)

b)

Fig. 5 Simulation of fire in a high-rise building after 190.8 seconds (a) and after 280 seconds (b) from the beginning of fire

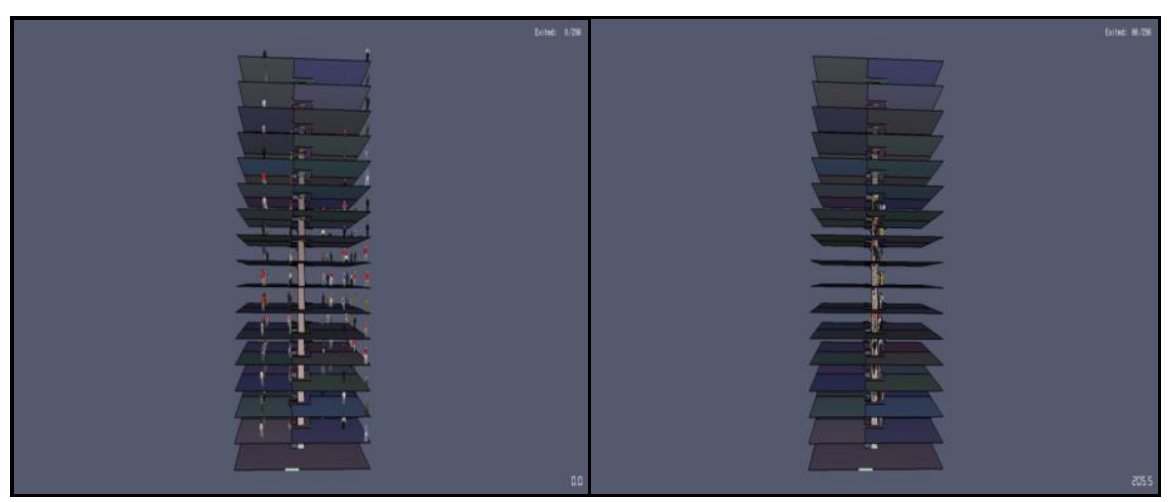

a)

b)

Fig. 6 Simulation of evacuation in a high-rise building at the start of the evacuation (a) and after 205.5 seconds (b), for the first scenario (speed of occupants was $0.7 \mathrm{~m} / \mathrm{s}$ ) 


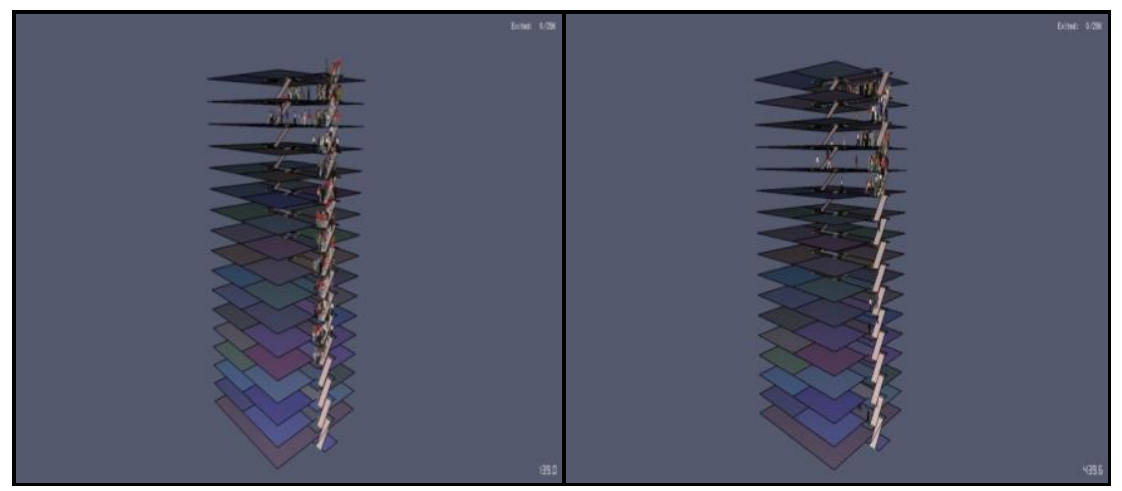

a)

b)

Fig. 7 Simulation of evacuation in a high-rise building after 139 seconds (a) and after 439.6 seconds (b), for the second scenario (speed of occupants was $0.7 \mathrm{~m} / \mathrm{s}$ )

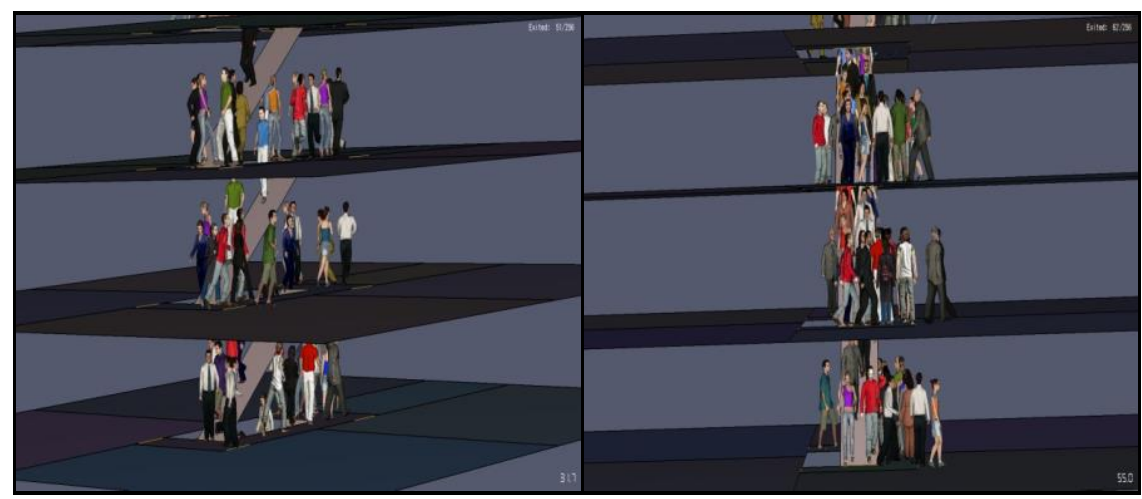

a)

b)

Fig. 8 Occupants are potentially stuck in case of different speed (a and b)

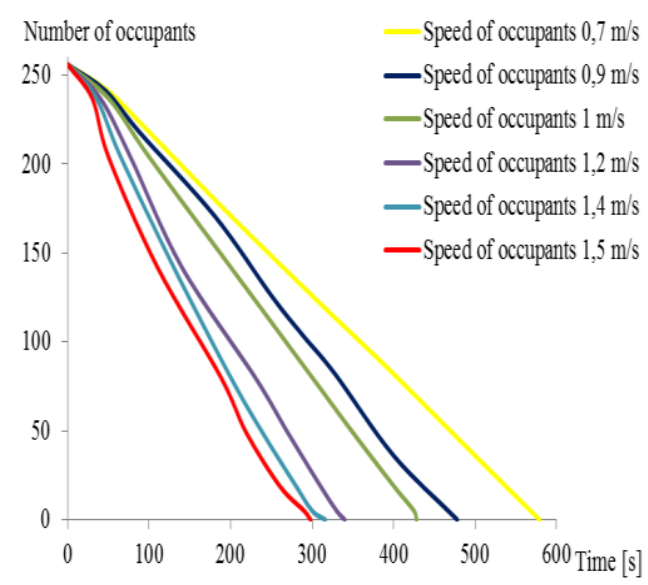

Fig. 9 The complete simulation results of evacuation times for the first scenario 


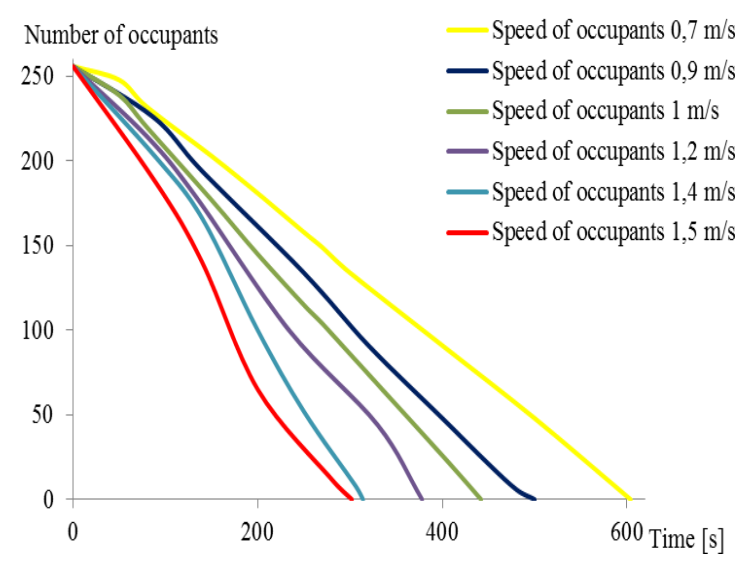

Fig. 10 The complete simulation results of evacuation times for the second scenario

\section{RESULTS AND ANALYSIS}

Simulation results in FDS showed potential fire and smoke spreading in a high-rise building for fire that started at the exact location. It was obvious that smoke progresses fast and fills great volume of the building which can be extremely dangerous for occupants in evacuation. In the first place, the contents of smoke (carbon monoxide, carbon dioxide, sulphur burning products, nitrogen burning products, halogen elements burning products and similar) can be fatal for occupants and fire brigadiers in very short time in terms of their toxicity and explosiveness. On the other hand, great quantity of smoke limits the field of vision and greatly complicates the occupants' movements and finding the exit. These objects must have some kind of ventilation in order to prevent smoke propagation. Ventilation that could be used can be natural or forced. It is possible to show the smoke particles and smoke spreading under some ventilation source and temperature distribution.

The results for the first evacuation scenario (figure 9) showed that all occupants could leave the building in case ofall simulated speeds of occupants. However, this was right only if all occupants had the same speed, which is highly improbable. Occupants can be easily stuck if there is small difference in the speed of their movement (figure 8), and that is almost impossible to calculate the time needed to leave the building. The presence of stress and panic can also create unthinkable situations and significantly impedes the evacuation. The elevators in building were not used for evacuation.

The results for the second evacuation scenario (figure 10) also showed that all occupants could leave the building in case of all simulated speeds, this time by fire stairs. All occupants had the same evacuation speed, just like in the first scenario. The evacuation times for the second scenario were longer than the evacuation times for the first scenario, as expected. In this scenario, minor differences in speed between different occupants caused stuck. The elevators in the building were not used for evacuation and for this scenario.

Both evacuation scenarios did not imply the existence of a wheelchair or hospital bed that must be evacuated, as presented in figure 11 . This can be a real situation- there are many old, weak and disabled people who should also be evacuated. This situation needs a 
very detailed and special preparation and evaluation. For example, the existence of only two wheelchairs at ninth and sixth floor can obstruct the complete evacuation, it can be delayed for twenty or thirty seconds or there can be a complete stuck.

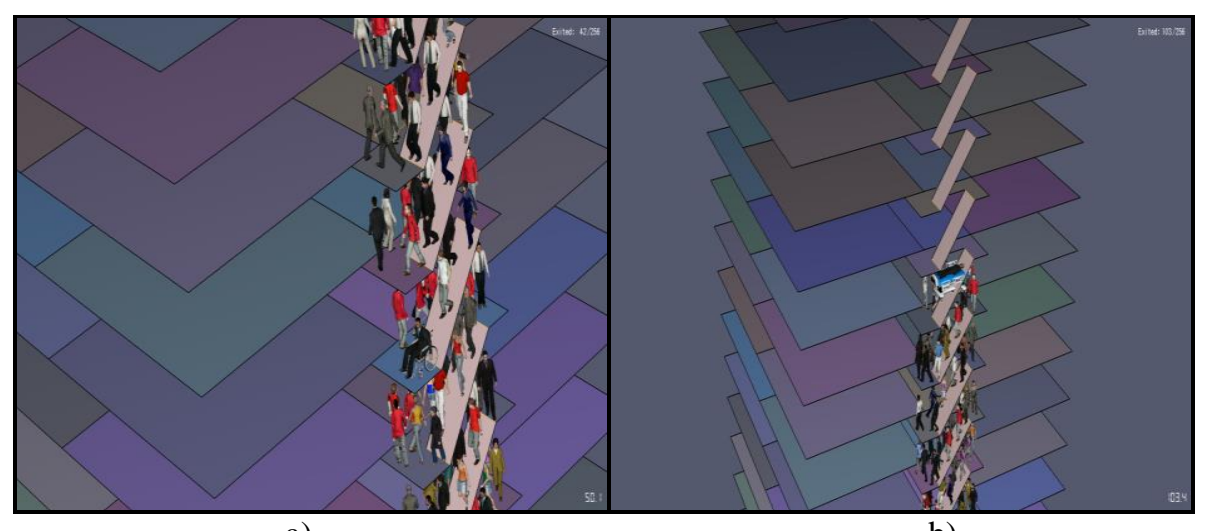

a)

b)

Fig. 11 Evacuation in cases of wheelchair (a) and hospital bed (b)

\section{CONCLUSION AND FUTURE INVESTIGATION}

The simulation results showed how complicated and difficult can be the evacuation of occupants from a tall object facility such as a high-rise residential building. Although simulation software showed a very good, safe and economic way of fire and evacuation prediction, it is not possible to completely provide the same conditions under fire, smoke, panic, stress and many other factors, which cannot be simulated. It is almost impossible to predict time in case when people get trapped in the evacuation route which can have fatal consequences for occupants. On the other hand, it is possible to calculate and to predict the occupants "flow" through evacuation routes and to predict potential areas and places where the occupants can get stuck, as well as to educate the occupants how to behave in situations of fire and evacuation. Also, after simulation and similar analyses, it is possible to predict the potential locations for fire detectors in order to provide proper fire detection time and obtain more time for evacuation.

However, as it has been mentioned previously, this is a problem that still needs to be settled. Better solutions, calculations and suggestions are always welcome. Therefore, simulation software is a very good tool for engineering calculations and tendencies to predict fire situations and preventive actions.

This paper presents a good basis for future investigations related to fire and evacuation prediction under different scenarios. The scenarios could include the persons with disabilities, the analysis of the influences of smoke and fire under evacuation, buildings higher than 100 meters, and similar. 


\section{REFERENCES}

1. Jevtić, R; Simulation of the shopping centre "Zona I" evacuation, Tehnika Elektrotehnika, number 3/2014, Beograd.

2. Jevtić, R; Simulation of evacuation situations in order to protect human lives and material property, NBPJournal of criminalistics and law, number 2/2016, Beograd.

3. Jevtić, R and Ničković, J; Object evacuation for different speeds of occupants, 58thETRAN CONFERENCE, 2014, Vrnjačka Banja.

4. Jevtić, R and Ničković, J; Simulation of residential object evacuation, 57th ETRAN CONFERENCE, 2013, Zlatibor.

5. Jevtić, R, Blagojević, M; Simulation of the school object evacuation, Tehnika elektrotehnika, number 2/2013, Beograd.

6. Jevtić, R; Combustion as fire consequence-great danger for human health, Zdravstvena zaštita, number 9/2015, Beograd.

7. Jevtić, R; Evacuation from tunnels: An example of Straževica tunnel, Vojnotehnički glasnik, Vol 64., number 3/2016, Beograd.

8. Jevtić, R; Fire simulation in house conditions, Tehnika Elektrotehnika, number 1/2016., Beograd.

9. Jevtić, R; Heat detectors-Division, Positioning in Object and Simulation, Tehnika Elektrotehnika, number 2/2015, Beograd.

10. Jevtić, R; The importance of fire simulation in fire prediction, Tehnika Elektrotehnika, number 1/2014, Beograd..

11. Jevtić, R; The simulation of sanitary objects evacuation-an example of hotel Radon in Niška Banja, Tehnika elektrotehnika, number 3/2015, Beograd.

12. NFA; Fatal fires in residential buildings, Topical fire report series, Vol 11, 2010, USA.

13. Thunderhead, Pathfinder Example Guide, 2018, USA.

14. http://www.businessdictionary.com/definition/evacuation.html

15. https://en.wikipedia.org/wiki/Casualties_of_the_September_11_attacks

16. http://mondo.rs/a937950/Info/Svet/11.-septembar-napad-na-Njujork-i-Vasington-kule-bliznakinje.html

17. http://news.bbc.co.uk/2/hi/uk_news/4145219.stm

18. https://en.wikipedia.org/wiki/2004_Indian_Ocean_earthquake_and_tsunami

19. http://www.politika.rs/scc/clanak/392509/Zemljotres-u-Iranu-Vise-od-328-zrtava-3-000-povredenih

20. https://rs.sputniknews.com/svet/201712291113983240-mumbaj-pozar/

21. https://www.blic.rs/vesti/svet/vatra-progutala-neboder-u-londonu-pronadena-ugljenisana-tela-jos-stotinunestalih/d0c7v5p

22. http://www.kurir.rs/planeta/2941377/video-stravicne-poplave-u-grckoj-dvoje-mrtvih-ljudi-zarobljeni-ukucama

23. Glavinić, P. and Rasković Đ.; Manual for preparation of candidats for professional exam from fire protection field, Meritus tim, ISBN 978-86-917589-91, Fourth edition, 2016, Beograd.

24. Ronchi, E. and Nillson, D.; Fire evacuation in high-rise buildings: a review of human behaviour and modelling research, Fire science reviews, 2013.

25. Australian Building Codes Board on behalf of the Commonwealth of Australia and States and Territories of Australia; HANDBOOK: LIFTS USED DURING EVACUATION, pp. 2013.

26. http://www.fireengineering.com/articles/print/volume-167/issue-6/apparatus-supplement/apparatuspurchasing-a-series-of-choices-compromises-and-trade-offs.html

27. https://www.arch2o.com/10-tallest-buildings-in-the-world-completing-in-2018/

28. https://sr.wikipedia.org/sr/Списак највиших структура у Србији

29. JUS TP 21; Tehnička preporuka za zaštitu od požara stambenih, poslovnih i javnih zgrada, SZS, izdanje I, pp. 19-22, Beograd, 2002.

30. McGrattan, B. K. and Forney, P. G.; Fire Dynamics Simulator - User's Manual, National Institute of Standards and Technology, January, 2000. 


\section{POŽAR I EVAKUACIJA U VISOKIM STAMBENIM ZGRADAMA}

Iako termin evakuacija podrazumeva najbrži, najbezbedniju $i$ najkraći put napuštanja ugroženog objekta, mesta ili situacije, to nije uvek slučaj sa ljudima, životinjama i vlasništvom. Mnogi objekti, zbog svojih osobina su veoma teški da bi se evakuisali uprkos svim sigurnosnim merama. Posebno teške za evakuaciju su visoke stambene zgrade i drugi visoki objekti sa mnogo ljudi u njima. Postoji mnogo razloga za to ali je jedan posebno važan i to je ponašanje ljudi $u$ stresnim i paničnim situacijama. Čak i pored svih sigurnosnih mera, edukacija i teninga, gotovo je nemoguće predvideti nečije ponašanje u stresnim i paničnim situacijama. Ovo može imati ogroman uticaj na process evakuacije tako što smanjuje verovatnoću za evakuaciju, utiče na nemogućnost evakuacije, zahteva duže vreme evakuacije i prouzrokuje moguće ljudske žrtve. Ovaj veoma važan $i$ otvoren zadatak uvek može imati bolje rešenje. Ovaj rad je napisan da pokaže važnost svih faktora potrebnih za analizu i upotrebu svih raspoloživih resursa da predvidi razvoj evakuacije $i$ zažtiti živote ljudi i materijalna dobra.

Ključne reči: evakuacija, zgrada, čovek, simulacija 